\title{
TANTANGAN PENDIDIKAN ISLAM DI INDONESIA PADA ERA GLOBALISASI
}

\author{
Ahdar, ${ }^{1}$ Musyarif ${ }^{2}$ \\ Dosen IAIN Parepare \\ Email: ahdar@stainparepare.ac.id
}

\begin{abstract}
Globalization has brought about the transformation of social life in various segments. Open territoriality between countries by information and communication technology. This has implications for the dimension of life especially in the existence and projection of Islamic education. Islamic education faces multidimensional and complex challenges such as technology, ideology, social, cultural, economic and political. Other challenges are professionalism, integrity, solidarity and vision. Present and future educational solutions with increased human resources include the ability to give birth to humans who can contribute to national development; the ability to produce human beings who can appreciate, enjoy and maintain the results of development, and the ability to produce humanitarian and humanitarian processes continuously towards a nation that is just and wise. Islamic education provides an effective and efficient solution in managing the social life system in the midst of multidimensional globalization.
\end{abstract}

Keyword: Islamic education, globalization, solutions

\begin{abstract}
ABSTRAK
Globalisasi telah membawa dampak transformasi kehidupan sosial di berbagai segmen. Terbuka territorial antar negara oleh teknologi informasi dan komunikasi. Hal tersebut berimplikasi kepada dimensi kehidupan terutama kepada eksistensi dan proyeksi pendidikan Islam. Pendidikan Islam menghadapi tantangan multidimensi dan kompleks seperti teknologi, ideologi, sosial, budaya, ekonomi, dan politik. Tantangan lain adalah profesionalisme, integritas, solidaritas, dan visi. Solusi pendidikan masa kini dan yang akan datang dengan peningkatan SDM, meliputi kemampuan melahirkan manusia yang dapat memberikan sumbangan terhadap pembangunan nasional; kemampuan untuk dapat menghasilkan manusia yang dapat mengapresiasi, menikmati dan memelihara hasil-hasil
\end{abstract}


pembangunan, dan kemampuan melahirkan proses pemanusiaan dan kemanusiaan secara terus menerus menuju bangsa yang adil dan bijak bajik. Pendidikan Islam memberikan solusi yang efektif dan efisien dalam menata sistem kehidupan social di tengah globalisasi multidimensi.

Keyword: Pendidikan Islam, globalisasi, solusi

\section{PENDAHULUAN}

\section{Latar Belakang}

Peradaban manusia sekarang menghadapi cobaan yang dahsyat, persis yang dihadapi di negeri Yunani pada abad ketiga sebelum Masehi, disepanjang Arabia pada abad keenam Masehi, dan di Eropa pada abad kelima belas. Persamaannya adalah keruntuhan berbagai pola kehidupan yang biasa digunakan oleh manusia untuk menanggapi hidup ini. Munculnya pola baru dalam hal ini sama sekali belum dikenal orang sebelum itu yaitu sikap manusia terhadap cobaan hidup. ${ }^{1}$ Kerangka cobaan hidup itu runtuh dan segala kekuatan telah kacau balau maka orangpun lumpuh tak berdaya segala jalan tertutup. Si Aku (Ego) berdiri seorang dan terasing, tak ada yang mendorong ataupun menariknya. Begitu juga dengan kaum terpelajar dewasa ini. Kalau akan ditumpukan pada salah satu aspek dari krisis itu, yaitu krisis ekonomi, yang lebih konkrit yang bukan hanya dirasakan segelintir pemikir seperti halnya dengan nilai-nilai abstrak tadi tetapi juga terutama oleh rakyat jelata dan orang-orang dipinggir jalan terutama gejala meningkatnya pengangguran diseluruh dunia, maka lebih yakin lagi bahwa krisis-krisis ini tidak lebih dari penyakit yang lebih besar penyakit peradaban dengan kata lain apa yang akan kita saksikan sehari-hari sebagai krisis, pengangguran, misalnya, tidak lebih dari suatu yang induknya sebenarnya tersembunyi di permukaan air yang disebut dengan krisis "peradaban". 2

Perkembangan masyarakat dunia pada umumnya dan masyarakat Indonesia pada khususnya sudah memasuki masyarakat informasi yang merupakan kelanjutan masyarakat modern dengan ciri-cirinya yang bersifat

${ }^{1}$ Hasan Langgulung, Pendidikan Islam Dalam Abad ke 21 ( Cet.III;Jakarta:PT Pustaka Al-Husna Baru,2003),h.125

${ }^{2}$ Ibid., h. 127 
rasional, berorientasi ke masa depan, terbuka, menghargai waktu, kreatif, mandiri, dan inovatif. Sedangkan masyarakat informasi ditandai dengan penguasaan teknologi informasi, mampu bersaing, serba ingin tahu, imajinatif, mampu mengubah tantangan menjadi peluang dan menguasai berbagai metode dalam memecahkan masalah.

Dampak globalisasi sebagai akibat dari kemajuan di bidang informasi perdaban dunia merujuk pada sebuah pengaruh yang mendunia. Demikian pula keterbukaan terhadap arus informasi yang menyangkut perkembangan ilmu pengetahuan dan teknologi dalam era globalisasi ini memberikan dampak lingkungan dan masyarakat manusia. Manusia yang kreatif dan produktif inilah yang harus dijadikan visi pendidikan termasuk pendidikan Islam, karena manusia yang demikianlah yang didambakan kehadirannya dengan secara individual, sosial maupun nasional. Masyarakat akan sangat kecewa manakalah dunia pendidikan justru menghasilkan manusia yang malas, tradisional, kurang peka dan konsumtif. Begitu pentingnya kehadiran manusia yang produktif yang harus dihasilkan dari dunia pendidikan Islam ini. ${ }^{3}$

Situasi pendidikan yang demikian itu, pendidikan Islam harus memainkan peran dan fungsi kultural, yaitu suatu upaya melestarikan, mengembangkan dan mewariskan cita-cita masyarakat yang didukungnya. Dalam fungsi ideal ini pula sebuah lembaga pendidikan Islam juga bertugas mengontrol dan mengarahkan perkembangan masyarakat. Tentu saja fungsi kontrol pendidikan Islam tidak akan sama fungsi kontrol yang dijalankan lembaga-lembaga politik. Lembaga pendidikan (khususnya pendidikan tinggi Islam) melakukan kontrol dan pengaruh melalui evaluasi dan rekonstruksi. ${ }^{4}$ Inilah arah dan tujuan yang harus diperjuangkan oleh Pendidikan Islam dewasa ini dan yang akan datang.

\section{Permasalahan}

Kompleksitas problematika kehidupan kontemporer berimplikasi kepada pendidikan Islam yang penuh tantangan. Diskursus tersebut menjadi fokus kajian yang dirumuskan masalah dalam penelitian ini, adalah:

${ }^{3}$ Jusuf Amir Faisal, Reorientasi Pendidikan Islam ( Cet. I; Jakarta : Gema Insani Press, 1995), h.131

${ }^{4}$ Kuntowijoyo, Paradgma Islam Interpretasi untuk Asksi ( Cet. IV; Bandung : Mizan, 1991), h.394 
1. Bagaimana tantangan pendidikan Islam masa kini dan mendatang?

2. Bagaimana mengatasi pendidikan Islam masa kini dan mendatang?

\section{METODE PENELITIAN}

Penelitian ini menggunakan jenis penelitian kepustakaan (library research). Pendekatan penelitian adalah analisis teks dan informasi yang terkait dengan kajian. Sumber data penelitian ini adalah buku ilmiah, jurnal, hasil riset ilmiah, hasil kajian ilmiah, hasil seminar, dan sebagainya. Kaelan menyatakan bahwa, dalam penelitian kepustakaan kadang memiliki deskriptif dan juga memiliki ciri historis. ${ }^{5}$ Teknik pengumpulan data dilakukan dengan melakukan identifikasi wacana dari buku-buku, makalah atau artikel, majalah, jurnal, web (internet), ataupun informasi lainnya yang berhubungan dengan judul penulisan untuk mencari hal-hal atau variabel yang berupa catatan, transkip, buku, surat kabar, majalah, dan sebagainya yang berkaitan dengan kajian penelitian. Aktifitas analisis data model ini antara lain, reduksi data (data reduction), display data dan gambaran konklusi atau verifikasi (conclusion drawing/verification). Pendekatan analisis data ini adalah hermeneutika, yaitu metode pemahaman, yakni aktifitas interpretasi terhadap obyek yang mempunyai makna (meaning-full form) dengan tujuan untuk menghasilkan kemungkinan yang obyektif. ${ }^{6}$ Pernyataan pakar ditelaah dan diinterpretasikan terkait dengan masalah penelitian.

\section{PEMBAHASAN}

\section{Tantangan Pendidikan Islam Masa Kini dan Mendatang}

Pendidikan adalah sebuah program yang mengandung komponen visi, misi, tujuan, kurikulum, proses pembelajaran, guru, peserta didik, sarana dan prasarana, alat, biaya, manajemen pengelolaan, kelembagaan, lingkungan, kerjasama, sistem informasi dan evaluasi. Sebagai sebuah

\footnotetext{
${ }^{5}$ Kaelan, Metode Penelitian Agama Kualitatif Interdisipliner (Yogyakarta: Paradigma, 2010), h. 134

${ }^{6}$ Josef Bleicher, Contemporary Hermeneutic as Method, Philosophy and Critique (London: Routledge, 1980), h. 28.
} 
sistem komponen pendidikan tersebut memiliki hubungan fungsional antara yang satu dengan yang lainnya dengan titik tekan pada tercapainya visi, misi dan tujuan. ${ }^{7}$ Kelemahan pada salah satu komponen (SDM dan dana) yang sangat berpengaruh pada komponen lainnya demikian pula sebaliknya.

Dari sekian komponen pendidikan tersebut yang paling menentukan adalah komponen sumber daya manusia (SDM) yang dalam hal ini adalah guru. Karena demikian penting dan menentukan peran guru dalam keberhasilan pendidikan, seorang dapat berkata: "andai kata tidak ada kurikulum, ruangan dan komponen lainnya, namun masih ada guru kegiatan pendidikan akan tetap berjalan". Itulah sebabnya tidak mengherankan bahwa ketika Hirosima dan Nagasaki di bom oleh Amerika Serikat, yang ditanyakan lebih dahulu oleh Kaisar Jepang pada waktu itu adalah "berapa jumlah guru yang masih tersisa". 8

Saat ini situasi dan kondisi yang dihadapi oleh guru jauh berbeda dengan situasi dan kondisi tempo dulu. Kini guru hidup di era globalisasi yang selain mengandung tantangan yang berat, kompleks dan juga multi efek. Berbagai tantangan mau tidak mau harus dipecahkan oleh guru, agar tantangan tersebut berubah menjadi peluang menuju kepada kemajuan.

Daniel Bell, sebagaimana yang dikutip oleh Abuddin Nata dalam buku Manajemen Pendidikan, bahwa di Era global saat ini masyarakat dihadapkan kepada lima kecenderungan yang membawa dampak bagi kehidupan yang amat luas. Kelima kecenderungan tersebut adalah sebagai berikut.

a. Kecenderungan untuk berintegrasi dalam kehidupan ekonomi.

b. Kecenderungan untuk berpecah belah (pragmentasi) dalam kehidupan berpolitik.

c. Kecenderungan interdependensi (saling ketergantungan) antara Negara dengan Negara lain.

d. Kecenderungan semakin meningkatkan kemajuan dalam bidang ilmu pengetahuan dan teknologi dan selanjutnya mengubah secara radikal situasi pasar kerja.

${ }^{7}$ St. Wardah Hanafie Das dan Abdul Halik, "Manajemen Pengendalian Mutu Sekolah: Implementasi Pada SMA Negeri di Kota Parepare," Prosiding Seminar Nasional, Volume 02, Nomor 1, 2016, h. 73.

${ }^{8}$ Abuddin Nata, Manajemen Pendidikan, Mengatasi Kelemahan Pendidikan Islam Di Indonesia (Cet.III;Jakarta: Kencana, 2008), h.64 
e. Kecenderungan semakin tergesernya kebudayaan dan tradisi masa lalu oleh kebudayaan dan tradisi baru, yang selanjutnya menimbulkan penjajahan baru dalam bidang kebudayaan, terjadinya perubahan pola fikir, sikap, perilaku, berpakaian, tempat tinggal, pergaulan, pola komsumsi yang menimbulkan ketegangan dan benturan kebudayaan. ${ }^{9}$

Selanjutnya tantangan dunia pendidikan sangat sukar dan kritikal. Di antaranya dalam bidang ekonomi adalah rendahnya pendapatan perkapita, dan pendapatan nasional, lemah produksi dalam negeri, pengangguran, sandang pangan yang tidak sesuai pemeliharaan kesehatan dan tersebarnya buta huruf dengan meluas. Kelemahan dari ekonomi juga adalah ketidak seimbangan antar berbagai sektor dan dependensi dalam perdagangan, sains dan teknologi. Diantara gejala-gejala dalam kesulitan sosial adalah ketegangan dan perselisihan yang ditimbulkan oleh berbagai Negara, sedangkan dalam segi budaya adalah dualisme dalam sistem pendidikan, pemikiran yang diwarisi di zaman kolonial masih tetap bercokol dan memecah masyarakat-masyarakat tersebut, di samping menimbulkan perselisihan pikiran dan politik yang menghabiskan tenaga dan potensinya ${ }^{10}$.

Kenyataan sejarah bahwa pada awal perkembangan sains modern sekitar abad 16-17 masehi pernah terjadi perpecahan antara kaum keagamawan dan kaum ilmuwan, yang ditandai dengan sikap keras kaum agamawan Eropa (penganut geocentris) kepada penganut heliocentric seperti Convernicus, Bruno, Galileo, Kepler, dan lain-lainnya. Metodologi yang dikembangkan oleh mereka mengandalkan inderawi dianggap tidak ilmiah. ${ }^{11}$ Peradaban islam yang pernah dibangun oleh umat Islam selama berabad-abad sebagian ada yang terpelihara namun sebagian besar telah hancur. Dan sebagian lagi diambil oleh Eropa dan Barat. Peradaban yang dikembangkan oleh Eropa dan Barat tentu saja disesuaikan dengan nilainilai atau cita- cita kehidupan mereka yang bercorak sekuler, yang

\footnotetext{
${ }^{9}$ Ibid., h.66-67.
}

${ }^{10}$ Dikotomi Pendidikan menjadi problem mendasar bagi pendidikan Islam. Tereduksinya makna dan kandungan pendidikan Islam disebabkan oleh adanya ideologi dan kebijakan pendidikan yang memisahkan wilayah agama dan umum. Selanjutnya lihat St. Wardah Hanafie Das, Abdul Halik, dan Amaluddin, "Paradigm of Islamic Education in the Future: The Integration of Islamic Boarding School and Favorite School", Information Manajemen and Business Review, Vol. 8, No. 4, Agustus 2016, pp. 24-32.

11 Muhaimin, Paradgma Pendidikan Islam, Upaya Mengefektifkan Pendidikan Agama Islam Di Sekolah (Cet. IV; Bandung: PT. Rosdakaruya Ofset, 2008), h. 83-84. 
memisahkan urusan keduniaan dan urusan akhirat yaitu agama. Berbagai produk peradaban dalam bidang ilmu pengetahuan, sistem ekonomi, politik, sosial, dan lain-lain sebagainya bercorak sekuler. ${ }^{12}$

Sistem manapun yang berusaha mempersiapkan diri masa depannya misalnya sistem pendidikan menghadapi abad ke 21 tanpa memperhitungkan sistem raksasa seperti sistem pendidikan barat sekarang yang mempengaruhi hampir setiap aspek kehidupan akan menghadapi kegagalan total. Kekinian dan kedisinian menghasilkan kemandekan, disamping orang-orang yang memiliki pengaruh dan kekuasaan bertindak sewenang-wenang demi mempertahankannya. ${ }^{13}$ Begitu juga dia akan gagal total bila ia hanya menjadi penurut saja kepada sistem raksasa itu tanpa ada usaha untuk menciptakan sesuatu lepas dari jeratan sistem raksasa itu, sistem barat yang serba ada ini telah memandang negara-negara dunia lain tidak lebih daripada pasar besar yang siap untuk membeli hasil produksinya.

Jaques Delors mengatakan bahwa ada tujuh macam ketegangan yang akan terjadi serta menjadi ciri dan tantangan pendidikan masa yang akan datang yaitu;

1. Ketegangan antara global dan lokal, orang secara berangsur-angsur perlu menjadi warga negara dunia, tanpa tercabutnya akar budaya mereka, sehingga mereka turut aktif dalam berbagai kegiatan dunia.

2. Ketegangan antara Universal dan Individual, kita dapat mengabaikan harapan-harapan yang dijanjikan proses globalisasi dan juga resikoresikonya.

3. Ketegangan antara tradisi dengan kemodernan, bagaimana tradisi dapat menyesuaikan diri pada perubahan tanpa harus kembali kemasa lampau.

4. Ketegangan antara pertumbuhan-pertumbuhan jangka panjang dan jangka pendek.

5. Ketegangan antara perlunya kompetensi dan kesamaan kesempatan.

6. Ketegangan antara perluasan pengetahuan yang berlimpah ruah dengan kemampuan manusia untuk mencernanya.

7. Ketegangan antara ketegangan antara spiritual dengan material adalah tugas mulai pendidikan untuk mendorong untuk berbuat

\footnotetext{
${ }^{12}$ Abuddin Nata, Opcit. 125

${ }^{13}$ M. Quraish Shihab, Membumikan al-Qur'an, (Cet; 1 Bandung Mizan, 1992), h. 249.
} 
berdasarkan tradisi-tradisi dan pendirian-pendirian serta memberikan penghargaan penuh terhadap pluralisme. ${ }^{14}$

Dengan kemajuan ilmu pengetahuan dan teknologi dapat memberikan dampak positif dan dampak negatif, adakah kemajuan iptek itu mendekatkan kita kepada Allah ataukah menyebabkan kita jauh dari Allah bahkan bertambah ingkar dan bertambah tamak untuk mencari kepuasan dan kekuasaan sebanyak-banyaknya kalau ini yang menjadi tujuan menuntut ilmu maka ini juga tidak ada bedanya dengan peradaban Barat.

Roger Garoudy yang dikutip oleh Hasan Langgulung dalam bukunya Pendidikan Islam dalam abad 21. Ia telah lima abad menguasai dunia tanpa tandingan menghadapi jalan buntu dan segala usahanya menuju kepada bunuh diri:

1. Pada abad sosial, dunia Barat pada tahun 1982 membelanjakan 650 milliar dollar Amerika untuk membuat senjata dan bom yang kalau dibagi-bagikan kepada penduduk dunia maka setiap penduduk (perkapita) menerima 4 ton bom, dalam waktu yang sama 50 juta penduduk dunia ketiga mati kelaparan atau kurang makan.

2. Pada bidang perekonomian yang dikendalikan oleh gagasan pertumbuhan dan perkembangan mereka menuntut penambahan produksi baik berguna atau berbahaya atau malah membunuh.

3. Pada bidang politik dan hubungan luar negeri antara Negara-negara, keganasanlah merupakan bahasa yang paling kaku, yaitu kemaslahatan orang-orang, kelas-kelas, dan rakyat bertarung dengan sengitnya.

4. Bidang kebudayaan, memiliki ciri-ciri kehilangan makna dan tujuan hidup. Mereka menginginkan seni untuk seni ilmu untuk ilmu, spesialisasi demi spesialisasi, kehidupan berjalan tanpa tujuan.

5. Dalam bidang keagamaan mereka telah menghilangkan kuasa Tuhan yang tertinggi, dengan itu mereka telah menghapuskan dimensi hakiki dari manusia sehingga sukar membedakan antara disiplin dan anargi, dan antara hak dan bathil.

Ciri-ciri tantangan ketegangan tersebut di atas memberikan indikasi ke pasar pendidikan Islam ke depan untuk senantiasa berbenah diri untuk

${ }^{14}$ Redja Mudyahardjo, Pengantar Pendidikan, Sebuah Studi Awal Tentang Dasardasar Pendidikan Di Indonesia. Ed. 1-4 (Jakarta: PT . Raja Grafindo Persada, 2008), h.511514. 
selalu berupaya menata sistem pendidikan dalam mengantisipasi situasi global.

\section{Solusi Mengatasi Tantangan Pendidikan Islam Masa Kini dan Mendatang}

Praktis pendidikan akhir-akhir ini dirasakan tidak relevan lagi hanya melihat dari dimensi rutinitas, melainkan harus diberi makna mendalam dan bernilai bagi perbaikan kinerja pendidikan sebagai salah satu instrumen utama pengembangan sumber daya manusia (SDM) dan multi kemampuan kognitif, efeksi, dan psikomotorik. Karena kita telah memasuki abad ke 21 abad globalisasi yang menuntut kemampuan bermitra dan berkompetisi pada skala internasional. Abad ini merupakan perjalanan abad modern manusia, yang harus mampu kita tapaki secara kompetitif dalam konteks perkembangan dan persaingan global, sekaligus menjadi kemitraan antar bangsa.

Dengan menggunakan bahan sistem pendidikan nasional (Sisdiknas) yang butiran-butiran emasnya telah dirintis olek Ki Hajar Dewantara jauh sebelum Indonesia merdeka, rasa optimisme atas kinerja Diknas dalam mengembangkan SDM Bangsa terus membesit dalam khasanah pemikiran kita, untuk itu kinerja diknas khsusnya lembaga persekolahan dan lembagalembaga pendidikan luar sekolah (PLS), mulai dari perkotaan sampai ke pedesaan harus terus kita bangun sebagai upaya menemukan jati diri bangsa sesuai dengan cita-cita nasional sebagaimana tercantum dalam pembukaan UUD 1945. Islam juga memiliki ajaran yang khas dalam bidang Pendidikan. Islam memandang bahwa pendidikan adalah hak bagi setiap orang laki-laki ataupun perempuan berlangsung sepanjang hayat. ${ }^{15}$

Kini untuk kerja di visi diknas harus mampu secara signifikan meningkatkan kualitas SDM bangsa menuju panemuan jati diri dalam rangka menebus persaingan skala global atau kawasan, bahkan supregional. Bukan suatu kebetulan, bahwa kita tengah memasuki era yang disebut sebagai Abad Asia. Abad Asia menuntut seluruh bangsa tidak terkecuali para petani yang tinggal di pedesaan harus tampil secara kompetitif. ${ }^{16}$

Faktor SDM suatu Negara akan menentukan suatu Negara itu, apakah Negara itu terbelakang, sedang berkembang atau maju. Oleh karena

15 Abuddin Nata, Metodologi Studi Islam (Ed.11; Jakarta : PT. Raja Grafindo Persada, 2007), h.87.

${ }^{16}$ Sudarwan Damin, Agenda Pembaruan Sistem Pendidikan (Cet. II; Yogyakarta: Pustaka Pelajar, 2006), h.95. 
itu modernisasi pembangunan suatu Negara pada umumnya dan pembangunan ekonomi industri pada khususnya, mensyaratkan transformasi SDMnya tidak hanya dalam arti kognitif dan psikomotor, akan tetapi juga cara hidup keseharian dan bangga menjadi warga Negara. Keberhasilan pembangunan nasional Indonesia harus sejalan dengan sikap mental SDM yang mendukung proses pembangunan itu. Bahan pengembangan sumber daya manusia adalah pendidikan dan karena pendidikan itu harus mampu menghasilkan SDM dengan tiga kemampuan sekaligus; pertama, kemampuan melahirkan manusia yang dapat memberikan sumbangan terhadap pembangunan nasional. Kedua, kemampuan untuk dapat menghasilkan manusia yang dapat mengapresiasi, menikmati dan memelihara hasil-hasil pembangunan. Ketiga, kemampuan melahirkan proses pemanusiaan dan kemanusiaan secara terus menerus menuju bangsa yang adil dan bijak bajik. ${ }^{17}$ Dalam makna pertumbuhan dan perkembangan, pembangunan mensyaratkan kemampuan SDM untuk membangun, memelihara dan menyikapi secara positif hasil-hasil pembangunan. Termasuk didalamnya adalah rasa memiliki inventaris public dan privat serta sumber-sumber lingkungan hidup, lingkungan fisik dan non fisik.

Temuan iptek menyebarkan hasil yang membawa kemajuan, dan dampaknya terasa bagi seluruh umat manusia. Semua hasil temuan Iptek disatu sisi harus diakui telah secara nyata mempengaruhi bahkan memperbaiki taraf dan mutu hidup manusia. Disisi lain temuan dan kemajuan Iptek itu telah dapat mempengaruhi bangunan kebudayaan dan gaya hidup manusia. Era kemajuan Iptek ini perubahan global semakin cepat terjadi dengan adanya kemajuan-kemajuan dari Negara maju di bidang Teknologi Informasi dan Komunikasi. Teknologi komputer misalnya membanjiri setiap Negara, bangsa dan budaya tanpa mengenal batas bangsa Negara dan Budaya. Faksimili adalah teknologi cetak jarak jauh yang dapat mengirimkan pesan untuk siapapun, dimanapun, negara manapun dan bangsa apapun, serta bisnis dan institusi apapun.

Kenyataan semacam itu akan mempengaruhi nilai sikap atau tingkah laku kehidupan individu dan masyarakatnya. Karena itu segera mendapatkan jawaban mampukah kegiatan pendidikan Agama Islam itu berdialog dan berinteraksi dengan perkembangan zaman modern yang ditandai dengan Iptek dan Informasi, dan mampukah mengatasi dampak negatif dari kemajuan tersebut. Disisi lain bangsa Indonesia juga

\footnotetext{
${ }^{17} \mathrm{Ibid}$, h.78
} 
menghadapi krisis nasional baik di bidang ekonomi, politik, hukum ataupun yang lainnya. Krisis ini ternyata mengkhawatirkan semua pihak dan lapisan masyarakat. Dalam kodisi semacam itu masyarakat supaya masih berharap besar sekaligus menunggu-nunggu jasa dan peran yang disumbangkan oleh agama, yang didalamnya syarat akan dimensi moralitas dan spritualitas maupun aktualitasnya dan normatifitas maupun historisnya ${ }^{18}$.

Dimensi rohani yang digambarkan pendidikan Islam itu dapat dipahami tidak hanya sebagai semata-mata tenggelam dalam ibadah formal, sampai-sampai melupakan kewajiban dunia, dan kewajiban masyarakat terhadap anggota-anggotanya. Tetapi yang dimaksud bahwa pendidikan islam itu harus diasaskan atas dasar pokok, yaitu bahwa manusia itu adalah makhluk Allah dan diberi tugas untuk memikul amanah sedang makhlukmakhluk lain tidak. Ia di perintahkan hidup dipermukaan bumi sejalan dengan ajaran ilahi. Dari sini dapat disimpulkan bahwa proses terpenting dalam pendidikan yaitu membentuk pandangan dan tujuan Islam adalah:

a. Generasi muda harus didik menyembah Allah ikut perintahnya, menunaikan fardhu-fardhu ibadah, berpegang teguh segala tuntutannya sepanjang hidupnya.

b. Generasi mudah harus didik hidup dalam masyarakat yang sehat mengakui prinsip persaudaraan, kerjasama, partisipasi yang tegak diatas hak dan kewajiban dalam rangka sistem jaminan sosial yang diakui oleh Islam.

c. Generasi baru harus didik menggunakan akal sebab penggunaan akal merupakan keharusan bagi inti akidah yang pada dasarnya adalah tantangan terhadap akal tanpa pamri atau perantara.

d. Generasi baru haruslah didik bersifat terbuka terhadap orang lain dan menjauhi sifat menyendiri dan tanpa berlebihan menonjolkan dirinya, sebab peradaban islam tegak di atas dialog yang membina prinsip memberi dan mengambil.

e. Generasi baru harus didik menggunakan pemikiran ilmiah dan menggunakan pencapaiannya itu dalam perencanaan dan penyelidikan-penyelidikan karena Islam adalah agama terbuka tidak tertutup dan tidak memusuhi ilmu dari manapun sumbernya. ${ }^{19}$

Pendidikan sejati merupakan proses pembentukan masyarakat beradab, masyarakat yang tampil dengan wajah kemanusiaan dan

\footnotetext{
${ }^{18}$ Muhaimin, op.cit, h.86

${ }^{19}$ Hasan Langgulung, Op.cit., h.140-141
} 
pemanusiaan yang normal. Kata lain pendidikan adalah moralisasi masyarakat terutama peserta didik. Pendidikan dimaksudkan disini lebih dari sekedar sekolah melainkan pendidikan sebagai jaring-jaring kemasyarakatan. Sejatinya pendidikan persekolahan memfokuskan daripada pembentukan kemampuan nalar intelektual dan keterampilan motorik, pembentukan nalar emosional dan efeksi, termasuk perilaku bermoral, untuk sebagian besar tugas pendidikan dalam makna jaring-jaring kemasyarakatan.

Kesejahteraan masyarakat merupakan basis utama lahirnya masyarakat bermoral, dan keperkasaan bangsa dan membela Negara merupakan pondasi keamanan dan ketenteraman masyarakat, keinginan untuk mewujudkan masyarakat bermoral dalam tataran kehidupan yang adil telah menjadi agenda kerja dan perhatian para filosof masa lampau, sekarang dan yang akan datang, misalnya memaklumatkan bahwa tidak seorangpun dengan sukarela untuk berbuat kesalahan. Sejatinya manusia akan berbuat yang terbaik sepanjang yang dapat dilakukan meski yang terbaik versi ucapan dan perbuatannya itu belum tentu dinilai baik bagi yang lain, karena sudut pandang dan kepentingan yang berbeda. ${ }^{20}$

Menghadapi tantangan tersebut maka perubahan dan inovasi merupakan kata kunci yang perlu dijadikan titik tolak dalam mengembanngkan pendidikan nasional pada umumnya. Pengembangan tersebut tidak dapat dilakukan sendiri oleh pemerintah pusat dan daerah tetapi memerlukan masukan dan gerakan bersama antar semua instansi, baik institusi pendidikan (dasar, menengah, atas dan tinggi), institusi ekonomi, politik, sosial, budaya, agama, serta masyarakat pada umumnya untuk mendukung cita-cita tersebut. ${ }^{21}$

Untuk memanaj perubahan tersebut perlu bertolak dari visi yang jelas yang kemudian dijabarkan misi dan didukung oleh skil insentif sumber daya (fisik dan non fisik termasuk SDM) untuk selanjutnya diwujudkan dalam rencana kerja yang jelas dengan demikian akan terjadilah perubahan. Jika salah satu aspek saja ditinggalkan maka akan mempunyai ekses tertentu misalnya jika visi ditinggalkan atau dalam pengembangan sekolah atau madrasah tidak bertolak dari visi yang jelas maka akan berakibat hancur. Perubahan atau inovasi itu hanyalah alat bukan tujuan. Apa yang dituju oleh

\footnotetext{
${ }^{20}$ Sudarwan Danim, Op.cit., h.66

21 Muhaimin, Nuansa Baru Pendidikan Islam, Mengurai Benang Kusut Dunia Pendidikan (Jakarta:PT. Raja Grafindo Persada, 2006), h.73
} 
perubahan itu adalah peningkatan mutu pendidikan, sehingga institusi pendidikan dituntut untuk menyelenggarakan dan mengelola pendidikan dengan serius.

Pendidikan dipandang unsur pokok dalam pembangunan. Pendidikan memberi sumbangan dalam menciptakan golongan yang terpelajar dan mengkhusus dalam pembangunan sumber-sumber material, selanjutnya dapat juga kita pandang pendidikan itu sebagai investment yang produktif yang memperlakukannya atas dasar itu. Ini bermakna bahwa pendidikan itu adalah industri produksi dimana dijalankan norma-norma produksi industri modern : pembelajaran, keuntungan, produktivitas, peluang dan kegunaan. Jadi sistim pendidikan itu adalah lembaga produksi yang harus tunduk pada analisis ekonomi supaya nilainya dapat diukur dan kegunaannya dapat dikenal pasti dan pemanfaatannya nyata.

Pembangunan berarti pertumbuhan produksi dan bertumpuknya kekayaan material. Ahli-ahli ekonomi liberal percaya bahwa pertambahan itu disatu segi akan membawa secara spontan kepada perbaikan tingkat hidup seluruh anggota masyarakat yang akan menciptakan keserasian hubungan sosial, sedang disegi lain akan memberi peluang bertambahnya kebudayaan dan pemikiran. Tetapi disegi lain pengalaman menunjukkan bahwa pertumbuhan produksi tidak harusnya membawa perbaikan pada tingkat semua golongan masyarakat tetapi hanya segelintir saja yang mendapat faedah dari pertumbuhan ekonomi itu sedang golongan-golongan lain tetap mengalami deprivasi. Juga disegi lain pendidikan tidak memberi sumbangan positif terhadap pertumbuhan ekonomi. Sebab tersebarnya pendidikan berlaku atas pengaruh faktor desakan sosial tanpa memperhitungkan keperluan-keprluan ekonomi, sehingga timbul ketidak seimbangan antara produksi pendidikan dan kebutuhan pembangunan, misalnya lulusan-lulusan institusi pendidikan dan kebutuhan pembangunan. Satu segi sistim pendidikan diisi oleh sejumlah besar orang-orang terpelajar yang hanya sedikit saja mereka itu bersifat produktif, sedang sejumlah besar menganggur. Disegi lain ekonomi sangat memerlukan orang-orang yang memiliki keterampilan menengah atau spesialisasi diberbagai sektor (pertanian dan industri maju), akibatnya penyebaran pendidikan secara random menyebabkan ia tidak berfungsi secara ekonomis. ${ }^{22}$

Namun pengalaman ini juga menunjukkan bahwa masalah pendidikan dan pembangunan bukanlah masalah ekonomi semata-mata, tapi

${ }^{22}$ Hasan Langgulung, Op.cit, h.131-132 
mempunyai unsur-unsur sosial, politik, budaya, pemikiran dan spiritual yang tidak dapat diabaikan dan dipisahkan sama sekali. Pengabaian inilah yang menimbulkan gambaran-gambaran salah dan masalah berkepanjangan yang dilalui oleh sistem-sistem pendidikan baik di dalam Negeri maupun di luar Negeri.

Profesional dalam peran sertanya dalam pembangunan peradaban Islam masa mendatang dapat terwujud apabila umat Islam dapat melakukan hal-hal sebagai berikut: (a) Dapat menguasai pendidikan yang bermutu secara lebih variatif, yakni tidak menguasai bidang agama saja, melainkan juga bidang pengetahuan umum, (b). Perlu adanya wadah yang mempersatukan seluruh potensi yang dimiliki oleh kaum professional muslim saat ini. (c). Para elit politik dan birokrat muslim yang saat ini memiliki peluang begitu besar, hendaknya lebih mengutamakan kepentingan umat Islam daripada kepentingan pribadi dan golongan. (d). Berbagai saluran ekonomi, komunikasi dan pembentukan opini publik seperti peralatan komunikasi, koran, dan sebagainya harus dikuasai oleh umat Islam.

Untuk mengatasi berbagai kemelut bagi bangsa, agama dan pendidikan khususnya maka kini tengah dicari konsep yang tepat untuk menggantikan konsep masyarakat model sebelumnya yang dinilai banyak mengandung berbagai kelemahan. Konsep yang diharapkan dapat mengatasi permaslahan kemasyarakatan tersebut adalah konsep masyarakat Madani. Sementara itu pendidikan Islam sebagai sarana pembentukan dan penyiapan umat manusia diharapkan mampu memberikan konstribusi bagi upaya mewujudkan masyarakat Madani. ${ }^{23}$ Dasar-dasar masyarakat Madani (beradab) tersebut telah dibangun oleh Nabi Muhammad Saw. dan kemudian dikembangkan oleh para Khulafa Al Rasyidin (Khalifah yang bijaksana). Jadi masyarakat Madani adalah masyarakat yang beradab, yaitu masyarakat yang seluruh aspek hidupnya didasarkan pada nilai-nilai Ilahiah yang universal seperti egaliter, kejujuran, demokratis, manusiawi, kemitraan, kejujuran dan keikhlasan. Untuk mewujudkan keadaan masyarakat yang demikian itu bdapat dicapai dengan pendidikan Islam, karena pendidikan Islam dengan berbagai aspeknya didasarkan pada nilanilai yang luhur dan Universal. Langkah-langkah strategis lainnya adalah dengan mewujudkan keteladanan diri para pendidik dan pemimpin

\footnotetext{
${ }^{23}$ Abuddin Nata, op.cit., h.31
} 
masyarakat menumbuh kembangkan kebersamaan dan melaksanakan da'wah bilhal.

\section{KESIMPULAN}

Tantangan pendidikan Islam kontemporer, adalah dikotomi pendidikan, kualitas sumber daya manusia, globalisasi politik dan ekonomi, toleransi antar umat beragama, kemampuan anggaran, sistem manajerial lembaga pendidikan Islam, akselerasi teknologi informasi dan komunikasi, radikalisme, pencemaran lingkungan, kesenjangan sosial, kekaburan identitas, termasuk sekularisme, liberalisme, dan pluralisme. Tantangan pendidikan Islam dapat diklasifikasi ke dalam bidang teologi, ekonomi, politik, sosial, budaya, teknologi, dan kepemimpinan.

Solusi pendidikan masa kini dan yang akan datang dengan peningkatan SDM. SDM yang baik akan memiliki ciri-ciri sebagai berikut; pertama, kemampuan melahirkan manusia yang dapat memberikan sumbangan terhadap pembangunan nasional. Kedua, kemampuan untuk dapat menghasilkan manusia yang dapat mengapresiasi, menikmati dan memelihara hasil-hasil pembangunan. Ketiga, kemampuan melahirkan proses pemanusiaan dan kemanusiaan secara terus menerus menuju bangsa yang adil dan bijak bajik. Dalam makna pertumbuhan dan perkembangan, pembangunan mensyaratkan kemampuan SDM untuk membangun, memelihara dan menyikapi secara positif hasil-hasil pembangunan. Dalam makna pertumbuhan dan perkembangan, pembangunan mensyaratkan kemampuan SDM untuk membangun, memelihara dan menyikapi secara positif hasil-hasil pembangunan. Termasuk di dalamnya adalah rasa memiliki inventaris publik dan privat serta sumber-sumber lingkungan hidup, lingkungan fisik dan non fisik.

\section{DAFTAR PUSTAKA}

Bleicher, Josef. Contemporary Hermeneutic as Method, Philosophy and Critique. London: Routledge, 1980.

Damin, Sudarwan, Agenda Pembaharuan Sistem Pendidikan Cet. II; Yogyakarta: Pustaka Pelajar, 2006.

Faisal, Jusuf Amir, Reorientasi Pendidikan Islam Cet. I; Jakarta: Gema Insani Press, 1995. 
Hanafie Das, St. Wardah, Abdul Halik, dan Amaluddin, "Paradigm of Islamic Education in the Future: The Integration of Islamic Boarding School and Favorite School", Information Manajemen and Business Review, Vol. 8, No. 4, Agustus 2016, pp. 24-32.

-----------, dan Abdul Halik, "Manajemen Pengendalian Mutu Sekolah: Implementasi Pada SMA Negeri di Kota Parepare," Prosiding Seminar Nasional, Volume 02, Nomor 1, 2016.

Kaelan, Metode Penelitian Agama Kualitatif Interdisipliner. Yogyakarta: Paradigma, 2010

Kuntowijoyo, Pradagma Islam Interpretasi untuk Asksi Cet. IV; Bandung: Mizan, 1991.

Langgulung, Hasan, Pendidikan Islam Dalam Abad ke 21 Cet. III; Jakarta: PT. Pustaka Al-Husna Baru, 2003.

Nata, Abuddin, Manajemen Pendidikan Mengatasi Kelemahan Pendidikan Islam Di Indonesia Cet. III; Jakarta: Kencana, 2008.

Metodologi Studi Islam Edisi 11; Jakarta: PT. Raja Grafindo Persada, 2007.

Mudyahardjo, Redja, Pengantar Pendidikan, Sebuah Studi Awal Tentang Dasar-dasar Pendidikan Di Indonesia Ed.1-4 Jakarta: PT. Raja Grafindo Persada, 2008.

Muhaimin, Nuansa Baru Pendidikan Islam, Upaya Mengefektifkan Pendidikan Agama Islam Di Sekolah Cet. IV; Bandung: PT. Rosdakarya Ofset, 2008.

Shihab, M Qurasib, Membumikan Al-Qur'an Cet. I; Bandung: Mizan, 1992. 